Forest Bulletin No. 67 (Silvieulture Series): Chir (Pinus longiflora) Seed Supply. By S. H. Howard. Pp. 7. (Calcutta: Government of india Central Publication Branch.) 3 annas; $4 d$.

Koninklijk Magnetisch en Meteorologisch Observatorium te Batavia. Verhandelingen No. 14: Regenval in Nederlandsch-Indie (Rainfall in the Netherlands Indies). Door (by) Dr. J. Boerema. Deel 1 (Vol. 1): Gemiddelden van den Regenval voor 2715 Waarnemingsplaatsen in Nederlnndsch-Indië, berekend uit Waarnemingen verricht in het Tijdvak 18791922 (Mean Rainfall Figures for 2715 Rainfall Stations in the Netherlands Indies, calculated from Observations made during the Period 18791922). Pp. viii +192 . (Weltevreden : Landsdrukkerij.)


The American Museum of Natural History. Guide Leaflet No. 6l:
The Capture and Preservation of Small Animals for Study, By H. E. Anthony. Pp. 53. (New York.) 15 cents.

\section{Diary of Societies and Public Lectures.}

SATURDAY, JANUARY 9.

Geographical Associamron (Anmual Meetings) (at London School of Eeonomies), at 9.30 A.M.-Exhibition.-At 10.-Prof. P. M. Roxby : The Concept of Natural Regions in the Teaching of Geography, with Special Illustrations from China.-At 11.15.-Discussions heli concurrently in separate rooms:-C. G. Beasley and others : The Place of Geology in a Two Period a Week Geography Course.-C. D. Forde and others: Detail in Geography Lessons.-Major A. G. Church and others: Geography in Relation to other \$chool Suhjects.-Miss R. M. Fleming and others: Geography for the Younger Children in Primary Schools.

Institurion of Municipal and County Engineers (Yorkshire District) (at 'l'own Hall, Huddersfield), at 2.30 .

Royal Institution of Great Britain, at 3.-Sir William Bragg: Old Trades and New Knowledge: (6) The Trade of the Miner.

InstituTE of BRitish Foundrymen (Lancashire Branch) (at College of Technology, Manchester), at 4.-J. Longden: Liquid Shrinkage in Grey Iron.

$$
\text { MONDAY, JANCARY } 11 .
$$

ROYAL IRISH ACADEMy, at 4.15 .

Royal SocizTy of EdinburoH, at 4.30--Prof. A. A. Lawson - Endemism and Evolution as observed in the Australian Flora.-Prof $G$, Harrower: A Study of the Hokien and Tamil Skull. - Dr. D. A. Fairweather: Electrosynthesis in the Series of Normal Dibasic Acids. Firweather : Miectrosynthesis in the Series of Normal Dibasic Acids. - Miss C. C. of Water Vapour on Phosphorus Trioxide.-E. T. Copson: Partial of Water Vapour on Phosphorus Trioxide.-E. T.
Differential Equations, and the Calculus of Variations.

Differential Equations, and the Calculus of Variations.
Victoria INstitute (at Central Buildings, Westminster), at 4.30.Prof. T. G. Pinches : Notes on the Discoveries at Ur and Tel Al.Obeid, and the Worship of the Moon-God.

Institution OF AUtomobile ExGineers (Birmingham Centre) (at Chamber of Commerce, Birmingham), at 7.-H. Briggs: The Elinination of Noise in the Motor Cycle.

INSTITUTION OF ELECTRICAL. ENGINEERS (Informal Meeting) (at University College), at $7 .-W$. C. Clinton and others: Discussion on The Electrical Installation at the Rockefeller Building, University College.

Institution of Electrical Enginer:rs (North-Eastern Centre) (at Armstrong Cellege, Neweastle-upon-Tyne), at 7.

Institution of Mechanical Engineers (Graduates' Section, London), at 7.-E. H. Lewis: The Reduction of Factory Costs.

INSTITUTE of METALs (Scottish Local Seetion) (at 39 Elmbank Crescent, Glasgow), at 7.30.- - Prof. F. C. Thompson: The Mechanical Properties
Glite

of Non-Ferrous Metals and Alloys at High Temperatures.
Surveyors' Institution, at $8 .-$ W. L. Taylor: Recent Forestry Development.

Development.
ROYAL GrograPHICAL Society (at Eolian Hall), at 8.30.-J. P. Mills : RoYal GFographical SocieT
The Assam-Burma Frontier.

Royal Society of Mediojne, at 8.30.-Prof. Noël Paton: The Metabolic Changes in Chloroform Poisoning.

InstituTe of BrewiNa (Lrindon Section) (at Engineers' Club, Coventry Street, W.).-J. Stewart: Barleys.

institution of Electrical ENGiNeERs (Western Centre) (at Swansea).-R. A. Chattock: Presidential Address.

\section{TUESDAY, JANUARY 12.}

Manchester Geological and Mining Society, at 4

ROYAL Society OF MEDICINE (Therapentics and Pharmacology and Medicine Sections), at 5.-Prof. Elliott and Prof. Cummins and others: Discussion on The Treatment of Pulmonary Tuberculosis with Sanocrysin.

Institution of Petroleum Technologrsts (at Royal Society of Arts), at $5.30 .-$ J. Stanley Lewis : The Vapour Pressures of Fuel Mixtures,
Part II., to be followed by a discussion, opened by Prof. J. S. S. Brame, on The Estimate of Unsaturated and Aromatic Hydrocarbons.

I NSTITUTION OF Crvic ENoINEERs, at 6.-C. F. Bengough : High. Jevel Bridge, Newcastle-upon-Tyne: Underpinning and Repair of Foundations of River Piers.

Institurion of Eiectrical ENgineers (North Midland Centre) (at Hotel Metropole, Leeds), at 7 .

INSTITUTION OF EIECTRICAL ENGINEERs (Scottish Centre) (at North British Station Hotel, Edinburgh), at 7.-H. M. Sayers: Electricity Supply Tarifts.

Royal Photographic Society of Great Britain, at 7.-A. S. Watson : The Influence of the Renaissance on Italian Painting.

Instimetion of Automoblle Engineris (Coventry Centre) (at Broadgate INTIT
Café, Coventry), at 7.30. - J. D. Parkes: Lngic applied to Failures.

Society of Crfmical Indusrry (South Wales Section) (at T'echnical College, Cathays Park, Cardit), at 7.30.-Discussion on The Training of Chemists for Industry.

Institution of ENGINeERs and Shipbuilders in Scotland (at 39 Eimbank Crescent, Glasgow), at 7.30.-Prof. W. Kerr: Failure of

Metals by Creep.
QUeketT Microscopical Club, at 7.30.-T. Sarory : Evolution in Spiders. NO. 2932, VOL. I I 7 ]
Pharmaceutical. Socrety of Great Britain, at 8.-F. Browne and Dorothy G. Randle: Some New, Modified and Tested Formulæ of the British Pharmaceutical Codex.

\section{WEDNESDAY, JANUARY 13.}

Royal Society of Arts, at 3.-Prof. H. E. Armstrong: Alice in Wonderland at the Breakfast Table (Mann Juvenile Lectures) (2). RoYal Society OF MEDicine (Surgery: Sub-Section of Proctology), at 5.30,-Dr. C. Dukes: Simple Tumours of the Large Intestine and their Relation to Cancer. (To be followed by a discussion.)

Institution of Oivil ENGineers (Informal Meeting), at 6.--F. J. Paice: The Testing and Examination of Materials for Rallway Construction. Radio Societr of Great Britain (Informal Meeting) (at Institution of Electrical Engineers), at 6.

Institution of Electrical Enginekrs (South Midland Centre) (at Birningham University), at 7.-C. E. Webb: The Power Losses in Magnetic Sheet Material at High Flux Densities.

Institution of Chemical Engineers (jointly with Soeicty of Chemical Industry (London Section)) (at Chemical Society), at 8.- A. J. V. Industry (London Section)) (at Chemical Society), at 8. - A. J. V.
Underwood: A Critical Review of Published Experiments in Filtration. Underwood: A Critical Review of Published Experiments in Filtration. Grinding in a Current of Air.

InstiTution of ENGINeERS-IN-Charge (at St. Bride Institute, Bride Lane, E.C.), at 8.-J. W. L. Rowe: Industrial Economics.

Natitution of STructural Enginesrs (Lancashire and Cheshire Branch).-Prof. J. Husband: The Lateral and Transverse Bracing of Bridges.

\section{THURSDAY, JANUARY 14.}

Royal Society, at 4.30.-Dr. L. Hill and Y. Azuma: Effects of Ultra-Violet Radiation upon Involuntary Muscle and the supposed Physiological Interference of Visible Rays. - I. de B. Daly : A Closed Circuit Heart Lung Preparation. Effect of Alterations in the Peripheral Resistance and in the Capacity of the Circulation. - To be read in title only:-T. S. P. Strangeways and Honor B. Fell: Experimental Studies on the Differentiation of Embryonic Tissues growing in vivo and in vitro. I. The Development of the Undifferentiated Limb-bud $(a)$ when sub-
cutaneously grafted into the Post Einbryonic Chick, and $(b)$ when cultivated in vitro.-C. N. Long: Muscular Exercise, Lactic Acid, and the Supply and Utilisation of Oxygen. Part XIV. The Relation in Man between the Oxygen Intake during Exercise and the Lactic Acid Content of the Muscles.-K. F. Hetzel and C. N. Long: The Metabolism of the Diabetic Individual during and after Muscular Exercise. -W. G. Millar: The Diffraction Method of measuring the Diameter of Erythrocytes.

Lrythrocytes.
London Mathrmatical Societr (at Royal Astronomical Society), at 5 . British PsYcholonical Society (Education Section) (at University College), at 6.--Miss Margaret Drummond: The Nature and Training of the Imagination.

Institution OF Electrical EngineERs (Dundee Sub-Centre) (at University College, Dundee), at 7.30. - W. M. Mackay: Atmospheric Electricity.

Institution of Mechanical Engineers (Glasgow Branch) (Annual Meeting) (at Royal Technical College, Glasgow), at 7.30.-S. Couper : Economy of Fuel in Steam Generating Installations.

Institution of Mechanical Exgineers (Cardiff Branch) (Annual Meeting).

Institution of Mechanical Engineers (Liverpool Branch). - Third Report of the Marine Engine Trials Committee.

Orl and Culour Chemists association.

Institution of the RubBer Industry (Manchester Section) (at Man. chester).-H. C. Young: Steam and its Control as applied to Rubber Production Methods.

FRIDAY, JANUARY 15.

Royal Astronomical Society (Geophysical Discussion), at 5.-Prof. J. Joly: Radioactivity and the Earth's Surface History. Other speakers Dr. H. Jeffreys and $P$. Lake. In chair-Lord Rayleigh.

Dr. H. Jeffreys and $P$. Lake. In chair-Lord Rayleigh.
Institution of MeOHanical Engineers (Informal Meeting), at 7.INSTITUTION OF MEOHANICAL ENGINEERs (Informal Meeting
Disculssion: Novelties at the 1925 Engineering Exhibition.

Royal Photographic Society of Great Britaln, at 7.-A. C. Banfield and J. D. Johnston: Demonstration of Thiocarbamide Lantern Slide Making.

PHotomicrographic Society (at 20 Mortimer Street) (Members only), at 7.-J. W. Ogilvy : Demonstration of Recent Improvements in Microseopieal Apparatus.

INSTITUTE OF ME'TALS (Swansea Local Section) (at University College, Swansea), at 7.15.- Prof. F. C. Thompson: The Wire-Drawing

Process.
Junior Institution of ENGINeERs, at 7.30...J. Wolstenholme: The Commercial Bide of Foundry Work.

Instrute of Metals (Sheffield Local Section) (at Sheffeld University), at 7.30.-Prof. C. H. Desch : The Early History of Gold.

Institution of STructural ENgineErs (Midland Counties Branch) (at Birmingham), at 7.30.-W. E. Ballard: Metallisation with special Birmingham, at 7.30.-W. E. Ballard: Metallisation with special
reference to Zinc Coatings to prevent Corrosion of Structural steelwork. reference to Zine Coatings to prevent Corrosion of
InSTITUTION OF MECHANICAL ENGINEERS (Leeds Branch) (Annual INSTITUTION OF M ECHANICAL ENGINEERS (Lee
Meeting).-Prof. F. C. Lea: Repetition Stresses.

SATURDAY, JANUARY 16.

Scottish Junion Gas Association (at Royal Technical College, Glasgow) at $\gamma$-D. Garrie: Paper.

\section{PUBLIC LECTURES.}

MONDAY, JANUARY 11 .

Dyers' Hall (Dowgate Hill), at 6.--C. M. Whittaker: Artificial Silk Dyeing.

FRIDAY, JANUARY 15.

University College, at 5.-Prof. T. Borenius: Donatello. 